\title{
Human subjectivity in the prenatal period ${ }^{*}$
}

\author{
Podmiotowość człowieka w okresie prenatalnym
}

\section{Tadeusz Biesaga}

Faculty of Philosophy, Pontifical Academy of Theology in Krakow, Poland

ORCID: https://orcid.org/0000-0003-0863-4422 • tbiesaga@sdb.krakow.pl

\begin{abstract}
The article rejects various attempts to negate the subjectivity of human embryo, formulated among others in the Polish debate entitled 'Stem cells - life for life?' and organised by the Ministry of Scientific Research and Information Technology in 2003 and 2004. The Author thinks that the proposal to treat a human embryo as a deceased donor of organs, is wrong both in the field of embryology and philosophical anthropology. It is also wrong to question the subjectivity of human embryo using various criteria of growth (developed nervous system, brain, consciousness, participation in the life of society and looking after one's own interests). For these criteria do not define humanity but describe human being in various phases of expressions of his/her human nature. That is why it is not acceptable to make the right to life conditional on the stage and degree of the actualization of humanity. Furthermore, one cannot justify the deprivation of the subjectivity of human embryo because of medical progress and the so-called good of humankind. The acceleration of progress cannot be done at the cost of life of some group of human beings.
\end{abstract}

Keywords: human subjectivity, human embryo, stem cells, prenatal period

Streszczenie:W artykule odrzucono różne próby zanegowania podmiotowości embrionu ludzkiego, sformułowane m.in. w polskiej debacie „Komórki macierzyste - życie za życie?" zorganizowanej przez Ministerstwo Nauki i Informatyzacji w 2003 i 2004 r. Autora staje na stanowisku, że propozycja traktowania embrionu ludzkiego jako zmarłego dawcy narządów jest błędna zarówno w dziedzinie embriologii, jak i antropologii filozoficznej. Błędem jest także kwestionowanie podmiotowości embrionu ludzkiego za pomocą różnych kryteriów wzrostu (rozwinięty układ nerwowy, mózg, świadomość, udział w życiu społeczeństwa i dbanie o własne interesy). Kryteria te bowiem nie definiują człowieczeństwa, lecz opisują człowieka w różnych fazach wyrażania jego ludzkiej natury. Dlatego nie do przyjęcia jest uzależnienie prawa do życia od stopnia i poziomu urzeczywistnienia się człowieczeństwa. Ponadto nie można usprawiedliwić pozbawienia podmiotowości ludzkiego embrionu postępem medycyny i tak zwanym dobrem ludzkości. Przyspieszenie postępu nie może odbywać się kosztem życia jakiejś grupy ludzi.

Słowa kluczowe: podmiotowośćc człowieka, embrion ludzki, komórki macierzyste, okres prenatalny

\section{Introduction: for whom does biotechnology bring benefits and for whom it is a risk?}

The question about the subjectivity of the human embryo is nowadays particularly relevant, because the development of modern biotechnology does not so much threaten man in the postnatal period as in the prenatal period (Fukuyama 2002). The great liberation movements for the defence of subjectivity and human rights gradually abolished slavery, racism and classism to discover the dignity of every human being. If, in the era of the conquests of America or Africa, those who were most affected by

" This article was originally published in Polish as Biesaga, Tadeusz. 2004. "Podmiotowość człowieka w okresie prenatalnym." Studia Ecologiae et Bioethicae 2: 213-218. The translation of the article into English was financed by the Ministry of Science and Higher Education of the Republic of Poland as part of the activities promoting science - Decision No. 676/P-DUN/2019 of 2 April 2019. Translation made by GROY Translations. 
enslavement and to some extent destroyed were peoples living in those continents. On the other hand, during the period of industrialization, the working class was the group that was most harmed. Thus today, in the times of the emergence of biotechnology, those who are most disadvantaged are people in the prenatal period. We are faced with the danger of objectifying them and using them as the raw material for the production of technical and medical specific products

\section{Attempts to negate the subjectivity of the human embryo}

Various attempts to negate the subjectivity of the human embryo can be traced not only in world literature but also in the Polish debate entitled "Stem cells - life for life?", organised by the Ministry of Science and Information Technology ${ }^{1}$. The terminology used there by some representatives of politics, medicine and utilitarian ethics deprives the human embryo of its subjectivity. It does this both, in determining the beginning of life and in certain procedures that are directed against the life of a human embryo. Starting with the names of the procedures, let's ask if the so-called therapeutic cloning of a human embryo is therapeutic for it? Certainly, it is not. The fragmentation of a cloned human embryo into stem cells is not a therapy for it, but its euthanasia. The ethically correct name for this activity is euthanasic cloning for the therapy of others. If a person at one stage of its life is destined for organs for others, then we are not dealing with therapeutic transplantation, but with euthanasic transplantation.

\footnotetext{
${ }^{1}$ The discussion held at the Ministry of Science and Information Technology, entitled: "Stem cells - life for life?" consisted of five debates. In the first debate, which took place on 15 December 2003, representatives of science, politics and the Catholic Church took part; in the second debate on 8 March 2004, representatives of the Catholic Church and Catholic circles participated; in the 3rd, on 22 March 2004, representatives of other churches and religious associations; in the 4th on 19 April 2004 - representatives of circles supporting research on stem cells; and the $5^{\text {th }}$ debate, the so-called summing up debate on 23 April 2004 was attended by selected participants from previous meetings.
}

Is an embryo a deceased organ donor, as suggested in the above-mentioned debate by Prof. Wiesław Jędrzejczak and Prof. Jacek Zaremba? "From my perspective - states W. Jędrzejczak - an embryo is no different from an organ donor. Who's the organ donor? It is a person who, unfortunately, ceased to live in the sense that his brain died, but its individual organs are still alive"(MSIT 2003).

The above analogy is, however, incorrect both in the field of embryology and philosophical anthropology. An embryo is not a dead being. It has just entered the path of his development, it has started its life. It is not a deceased embryo that is implanted, but a living embryo that can continue to develop. Its further development as an individual human being would have been annihilated if it had died. The so-called therapeutic cloning is no different in the procedure from reproductive cloning. Nobody claims that in the case of reproductive cloning, the human embryo is dead.

Can the so-called spare embryos that will not be implanted be treated as dead, as the proponents of using them for stem cells suggest in this debate? That claim is also false. It mixes the environment as a necessary condition for life and development with the life of a given organism. The embryo lives as long as it lives. To say that the earth may run out of oxygen or livelihood someday is not to say that we are all dead. Also, the ability of a human foetus to exist independently of the mother's organism is not the criterion of being human. The fact that a human embryo requires the specific environment does not mean that it is not an individual organism and should be reduced to the environment in which it develops. It shouldn't e.g. reduce the baby to the incubator where it is staying. We also need the necessary environment for our life and development in the postnatal period. The cosmonaut on the moon is also a living person, although there are no conditions for human life there.

Can the so-called supernumerary and redundant human embryos from in vitro fertilization lose their subjectivity in 
relation to the so-called necessary and implanted ones? Can we take the ethical position that the existence of a person or a group of people is for some reason unnecessary for a given community, state, humanity and we have the right to deprive them of their lives? People cannot be divided into redundant and necessary. When opposing the death penalty of notorious criminals, we see that the right to life is not granted by the state, but inscribed in the nature and dignity of every human being.

Can the humanity and subjectivity of an embryo be made dependent on its parents, society, state? It is done in the thesis "wanted and unwanted children", or in the promotion of the so-called abortion on request. It is claimed that if a mother accepts the child and wants to give birth to it, then through this acceptance it becomes a subject and has the right to life, if not, it is not the subject and can be aborted. This position is particularly favoured by those who think in terms of Hegelian-Marxist philosophy and utilitarian ethics (Biesaga 2003). Meanwhile, someone's acceptance or lack of acceptance does not change the ontic and moral status of another human being. It is who it is; its right to life is not dependent on someone's arbitrariness. Children's right to life is not dependent on the parents' arbitrariness, and vice versa, the parents' right to life is not dependent on their children. Our right to life does not depend on whether someone accepts us or disapproves of us.

Does the human embryo become the subject gradually, acquiring the characteristics typical of an adult? Maybe it becomes a subject only after implantation, when the nervous system and the brain develop, or maybe later, when it is capable of independent existence, or maybe only after birth, or maybe only after the newborn infant is accepted by parents and society, and maybe even later when it will be able to consciously and maturely take responsibility for its interests? One can go further and ask if a person does not lose its subjectivity as a result of biological or mental illness, because then it cannot consciously and responsibly implement its life plans in the community (Biesaga 2001a; 2004; Vial, de Dios Correa, and Sgreccia 1998). Do we then have the right to life only in a short period of maturity, and then we lose it? All descriptive, phenomenalistic or functionalistic definitions of man make the same mistake in taking what is secondary in man for what is primary. The nature of man is primary and manifestations at various stages of our development are secondary (Spaemann 2001, 291-305). It is the nasciturus, possessing human nature, that is the subject, and not a set of some of its features, such as the nervous system, brain, consciousness, the ability to take care of one's interests, the degree of physical fitness or intelligence. Phenomenalistic, descriptive, functionalistic definitions of man describe the secondary reality and on their basis, they want to determine who is and who is not human. Human is everyone who has human nature. The developing sciences are describing the expression of this nature, and will be doing so in an even richer way. The human embryo is human by its nature, by belonging through it to the human family. A sufficient criterion for its humanity is the genetic criterion, more precisely - the genealogical one.

Excluding it from the human family using various descriptive criteria, taken from other stages of human life, is segregation and discrimination in which the value of the previous stage of development is disregarded in favour of a later stage.

A disabled or mentally ill person, despite its dysfunction and not meeting various criteria, is no less a person than a capable person. We are equal in terms of personal dignity, but we are different and we are not equal in terms of our biological-psycho-social-cultural personality (Biesaga 2001b). The right to life comes from the first, not the second. No one can draw a discriminatory thesis that some have more right to life and others less, that in this respect some are more equal than others.

Making the right to a life dependent on the degree of biological, psychological or social development, which Zbigniew 
Szawarski, for example, does in his utilitarian ethics, also presented in the afore-mentioned debate, is undermining the value of human life as such. It's a dangerous thesis. Consequently, by accepting this thesis, "it should be acknowledged," said Andrzej Szostek in response to this position in the discussed debate, "that also among born people, the value of life and the right to life of an individual will be proportional to the degree of the actualization of humanity. The child will have (...) smaller right [to live] than an adult, a sick person a little different from a healthy person, older and already very much flagging even smaller than a child, as it is not even a potentially developing person" (MSIT 2003).

\section{Can human embryo be objectified on account of the progress of medicine and the so-called good of humankind?}

Such a position in the debate suggested some politicians and scientists. We reject, however, moral justification of medical advances at the expense of experiments on prisoners in concentration camps. We defend ourselves against experiments on the patient for the development of scientific work. We oppose the testing of new drugs by rich pharmaceutical concerns on patients in poor countries. We defend ourselves against the practices of sacrificing the lives of a group of people or individuals for the so-called benefit of science, progress of civilization or humanity.

The biotechnology race is undoubtedly an enormous pressure to not to fall behind to catch up with the others. But doesn't the objectification of the human being in the prenatal period under pressure and fear de-humanize medicine and culture? Can't medicine build up technical progress along with moral progress, i.e. obtain stem cells from sources that do not raise ethical objections? (Biesaga 2003-2004).

Indeed, a physician who comes into contact with patients who cannot be helped but he would be able to help them if progress were to be accelerated by experimenting on other people and with technological use of cloned embryos, is subject to dramatic choices. It may seem that sacrificing less-developed human beings for more-developed adults and suffering humans is most rational. But is medicine authorized to make decisions about the death of one person for the sake of another? Isn't the thesis of victory over disease, over death a utopia in the name of which we want to make progress in shortcuts, by sacrificing one for another?

Will the abandonment of embryonic products stop the progress in medicine and cause a catastrophe in the treatment of diseases - as some statements of this debate scare. Such voices always arose when slavery, the colonialism of the poor over the rich, was abolished. It was said that without this objectification, civilization would fall. Today we can point out the abuses of Western civilization in the exploitation of Indians, people of Africa, and other countries exploited and destroyed for the so-called progress.

\section{Conclusion: does democracy have any mechanisms defending the subjectivity of an embryo?}

It seems to have but not enough. From the positive side, the right to life is defended by the Declaration of Human Rights, conventions or constitutions of individual countries. However, if this right is threatened, it can be effectively defended by participating in social and political protests. However, a person in the prenatal period, as well as the terminal ill, cannot participate in such processes. Therefore, it is left at the mercy of other groups associated with its interests. It is hardly surprising that it loses to the interests of adults, the interests of scientists, biotechnologists, and women's liberation movements. In this case, democracy fails, man in the prenatal period is dependent on the arbitrariness of those who, to the detriment of him, in debates, protests and pressures, are able to win right for themselves. Therefore, the way of treating a human being in the prenatal period in a given culture is a fundamental test of the degree of overcoming class egoism and a test of the humanism of this culture. 


\section{Bibliography}

Biesaga, Tadeusz. 2001a. „Antropologiczny status embrionu ludzkiego." W Podstawy $i$ zastosowania bioetyki, red. Tadeusz Biesaga, 101-113. Kraków: Wydawnictwo Naukowe PAT.

Biesaga, Tadeusz. 2001b. „Pojęcie osoby a jakość życia we współczesnej bioetyce." Sympozjum 1(9): 53-64.

Biesaga, Tadeusz. 2003. „Błąd antropologiczny i jego skutki w bioetyce." W Btad antropologiczny, red. Andrzej Maryniarczyk, i Katarzyna Stępień, 191-200. Lublin: Polskie Towarzystwo Tomasza z Akwinu.

Biesaga, Tadeusz. 2003-2004. „Etyczna ocena pozyskiwania komórek macierzystych." Bioetyczne Zeszyty Pediatrii 1: 86-97.
Biesaga, Tadeusz. 2004. „Status embrionu stanowisko personalizmu ontologicznego." Medycyna Praktyczna 7-8(161-162): 28-31.

Fukuyama, Francis. 2002. Our Posthuman Future. Consequences of the Biotechnology Revolution. New York: Picador.

MSIT (Ministry of Science and Information Technology). 2003. "Stem Cells - life for life?" (Warsaw, 15 December 2003). Conference paper.

Spaemann, Robert. 2001. Osoby. O różnicy między czymś a kimś. Warszawa: Oficyna Naukowa.

Vial Correa, Juan de Dios, and Elio Sgreccia. 1998. Identity and Statue of Human Embryo. Vatican City: Libreria Editrice Vaticana. 